\title{
Quality of Life and its Predictors Among Iranian Patients With Rheumatoid Arthritis: A Systematic Review
}

\author{
Azad Shokri ${ }^{1}$; Payman Mottaghi ${ }^{2}$; Kamal Qolipour ${ }^{3}$; Saeid Safiri ${ }^{4,}$; Najmeh Bahman Ziari ${ }^{5}$; \\ Mahboubeh Bayat ${ }^{6}$; Shabnam Izadi ${ }^{3} ;$ Hamed Fattahi $^{7}$ \\ ${ }^{1}$ Department of Health Management and Economics, Tehran University of Medical Sciences, Tehran, IR Iran \\ ${ }_{2}^{2}$ Department of Rheumatology, School of Medicine, Isfahan University of Medical Sciences, Isfahan, IR Iran \\ ${ }^{3}$ Iranian Center of Excellence in Health Management, Department of Health Services Management, Faculty of Management and Medical Informatics, Tabriz University of Medical \\ Sciences, Tabriz, IR Iran \\ ${ }^{4}$ Department of Public Health, School of Nursing and Midwifery, Maragheh University of Medical Sciences, Maragheh, IR Iran \\ ${ }_{6}^{5}$ Faculty of Health Service Management and Medical Information, Isfahan University of Medical Sciences, Isfahan, IR Iran \\ ${ }_{7}^{6}$ Health Services Management of Research Center, Institute for Futures Studies in Health, Kerman University of Medical Sciences, Kerman, IR Iran \\ ${ }^{7}$ Deputy of Development and Resource Management, Ministry of Health and Medical Education, Tehran, IR Iran \\ ${ }^{*}$ Corresponding author: Saeid Safiri, Department of Public Health, School of Nursing and Midwifery, Maragheh University of Medical Sciences, Maragheh, IR Iran. Tel:+98-9141005277, \\ E-mail: S-safiri@razi.tums.ac.ir
}

Received: October 15, 2014; Accepted: January 20, 2015

\begin{abstract}
Context: Rheumatoid Arthritis (RA) is a chronic disease accompanied by physical disabilities and a number of co-morbidities; it leads to remarkable economic burden, reduced productivity, and deteriorated quality of life (QOL).

Objectives: The current study aimed to provide a clear view of quality of life among the Iranian patients with Rheumatoid Arthritis through a systematic review.

Data Sources: The current study was conducted as a systematic literature review on the articles published from 2000 to 2013 in data bases such as: Google scholar, Science Direct, PubMed, IRANDOC, SID and Medlib and by keywords: quality of life, Rheumatoid Arthritis, Iran and, their Persian equivalents.

Study Selection: Finally, 10 articles were selected out of the 2065 assessed ones.

Data Extraction: In the first step, the extracted results were summarized in the extraction table, and then analyzed using the Forest plot. Results: Based on the Forest plot, six studies on the quality-of-life, met the inclusion criteria. Total QOL score was 47.5. In the reviewed articles $(n=10)$, different variables and factors were reported to affect the QOL in patients with RA. The most important factors affecting QOL were demographic factors, depression, and complications of RA, etc.

Conclusions: Due to the chronic nature of RA, promoting the QOL and adherence to therapies could be achieved through convincing the patients. Therefore, identification of weak points and planning for them at all levels; from individual to the community level is suggested.
\end{abstract}

Keywords: Rheumatoid Arthritis; Quality of Life; Iran

\section{Context}

Rheumatoid Arthritis (RA) is an autoimmune disease with unknown etiology, which involves the small joints of the hands and feet symmetrically (1). The exact cause of RA is unknown, but it is thought to be multi-factorial, with genetic predisposition and environmental factors. Symptoms of RA vary depending on the degree of inflammation and include: joint pain and stiffness, fatigue, anorexia, and low fever. RA can also manifest as a systemic autoimmune disease that affects the musculoskeletal, nervous, respiratory, cardiovascular, renal, and hematological systems (2). The prevalence of RA is $1 \%$ in the world and within 5-10 years of diagnosis, half of the patients with RA will be unable to work (3) and they may have difficulty to perform normal daily activities. Moreover, coincidence of the RA with physical disabilities and some other diseases leads to remarkable economic burden, reduced productivity, and deteriorated quality of life (QOL) (2). The QOL is defined as the perception of people about life, values, goals, standards, and interests $(3,4)$. The World Health Organization (WHO) also defines QOL as the way individuals perceive their own state within the framework of their culture and value systems that includes the objectives, expectations, standards and interests. In chronic diseases, increasing the QOL of the patient is as important as improving the medical status. Therefore, QOL measures are increasingly used for resource allocation and determination of treatment strategies (5). Also, studies indicated that QOL could be considered as one of the most important components of quality of medical and healthcare (6). According to the authors' best knowl-

Copyright (C) 2015, Ahvaz Jundishapur University of Medical Sciences. This is an open-access article distributed under the terms of the Creative Commons Attribution-NonCommercial 4.0 International License (http://creativecommons.org/licenses/by-nc/4.0/) which permits copy and redistribute the material just in noncommercial usages, provided the original work is properly cited. 
edge, no systematic review studies are published in Iran on the importance of QOL in patients with RA.

\section{Objectives}

The current systematic review aimed to conclude and provide a general and clear view of the results obtained from previous studies to use in planning and interviewing the QOL improvement among patients with RA.

\section{Data Sources}

A systematic review was conducted on the published articles from 2000 to 2013 in three English and five Persian electronic databases: Science Direct, PubMed and Google scholar for English and Google scholar, IRAN DOC, SID, and MedLib in Persian. The combination of the following keywords was used as search strategy: QOL, RA, Iran and, their Persian equivalents.

\section{Study Selection}

The eligible criteria for selecting articles were quantitative or qualitative studies on the QOL of patients with RA in Iran. The articles published in English and Persian were included. Also, all articles published from 2000 to 2013 were included in this study to control and minimize the effect of time on the patients' QOL due to the medical advancements, changes of patients' knowledge and life styles. Articles that measured QOL only by qualitative methods without releasing conceptual framework to predict QOL, and the articles such as: letter to the editors, and articles presented in seminars and conferences without full text, or resulted from implemented interventions and animal studies were excluded. First, all articles were screened based on their titles and abstracts. Afterwards, retained articles were reviewed in depth. Then eligible references were identified by the mentioned criteria, and 10 articles were selected and evaluated.

\section{Data Extraction}

Finally, seven out of the ten articles had eligibility for quantitative analysis based on Forest plot (Figure 1). From each study, the author, year, location, number of participants, demographics, tools, and correlation/relationship of factors were extracted. The extracted data were analyzed quantitatively by Forest Plot Viewer and Microsoft Office Excel 2007. Summary results were presented as weighted mean with $95 \%$ confidence interval (CI). Forest Plot Viewer was used to create Forest plot, and the graphical display of individual study results. Data were collected from the reported means, standard deviations, and the number of patients in each study. Measures were provided as QOL index using 95\% confidence intervals in Forest plot. Heterogeneity was assessed by I2 statistics by Excel 2007 software (7). To analyze qualitative factors affecting QOL, content analysis was done to code and combine main categories.

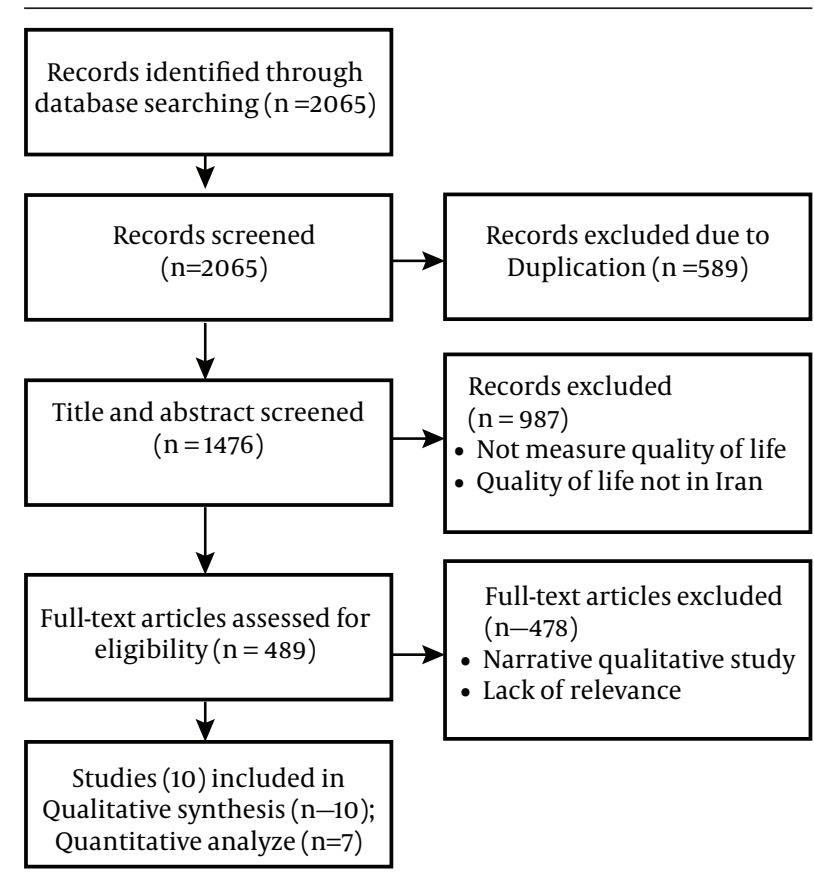

Figure 1. Flowchart of the Literature Search

\section{Results}

Two thousand and sixty five articles were found in the searched references. After studying titles, abstracts, and full texts of articles, and excluding duplicated and irrelevant cases, 10 articles were selected and evaluated according to the objectives of the study, among which four had been published in English journals. Most of the studies (five cases) were conducted in Tehran. The Most of the studies had been conducted in 2009. In the 10 investigated articles, quality of life for 1812 subjects was evaluated; majority of the cases were female (69.84\%). In the investigated articles, five different tools were used to evaluate the patients' QOL in Iran. Short Form Health Survey (SF-36) questionnaire was often applied, with 5 times in this study.

\subsection{Quality of Life Among Patients With Rheuma- toid Arthritis}

Six studies (8-13) that reported results of the QOL, met the inclusion criteria for assessment based on Forest plot. Total quality of life was 47.5. QOL score of three studies were lower than the mean. QOL score reported by Nadrian et al. (8) was 36.89 (95\% CI; 34.18, 39.6), suggesting the improving aspect of Role Function in patients with RA; QOL score reported by Askary-Ashtiani et al. (10) was 36.63 (95\% CI 35.7, 37.29), suggesting the improving aspect of Physical Role and General Health; and QOL score reported by Kalaly Jouneghani et al. (13) was 35.43 (95\% CI $33.68,37.16$ ), suggesting the improving aspect of Function (Figure 2). 


$\begin{array}{lcc}\text { Reference } & \text { Sample Size } & \text { Mean }(\mathbf{9 5} \% \mathbf{C I}) \\ \text { Nadrian, 2011 } & 181 & 36.89(34.18,39.6) \\ \text { Kolahi, 2011 } & 100 & 60.98(59.9,62.06) \\ \text { Kalaly Jouneghani, 2011 } & 23 & 35.43(33.68,37.16) \\ \text { Alishiri, 2011 } & 80 & 49.8(46.08,53.52) \\ \text { Pakpour, 2012 } & 197 & 64.33(59.98,68.68) \\ \text { Askary-Ashtiani, 2009 } & 350 & 36.63(35.7,37.29) \\ & & \\ \text { Summary } & 1281 & 47.65(46.85,48.44)\end{array}$

Heterogeneity: $\mathrm{Chi}^{2}=3.55, \mathrm{df}=(\mathrm{P}<0.0001) ; \mathrm{I}^{2}=69 \%$

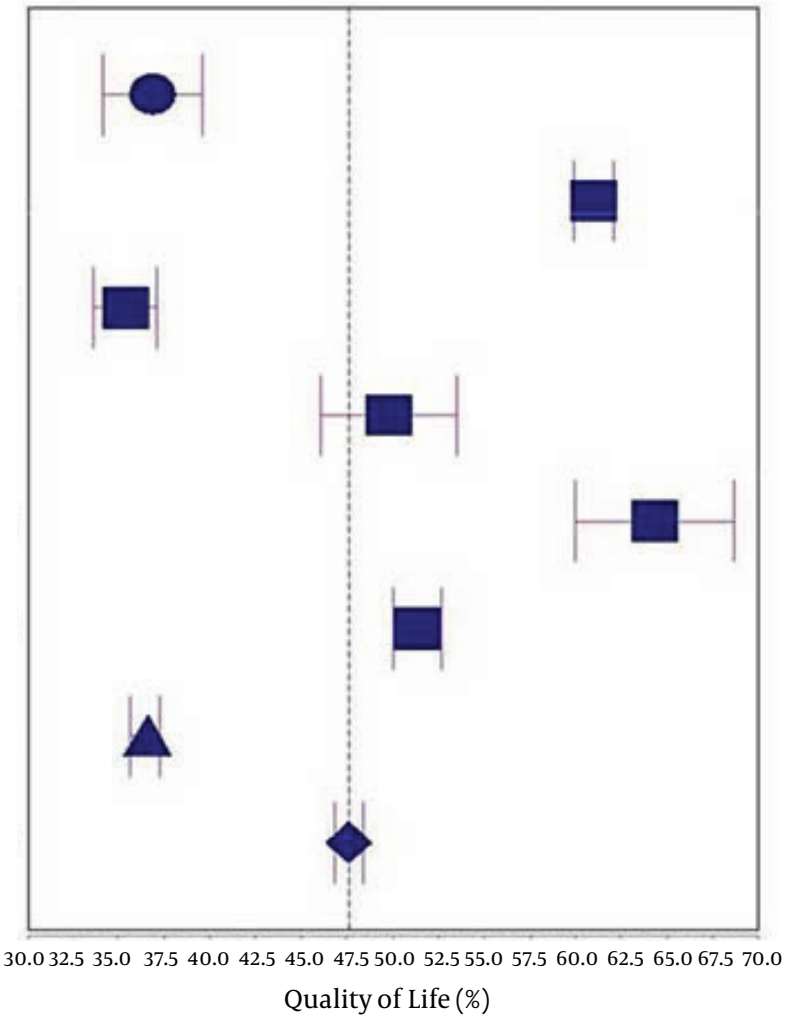

Figure 2. Forest Plot for Studies Reporting Quality of Life Among Iranian Patients With Rheumatoid Arthritis

\subsection{Factors Affecting Quality of Life}

In the reviewed articles, different variables and factors were reported to affect QOL of the patients with RA (8-17). One of the most thoroughly studied factors is depression which appears to be a key factor affecting quality of life $(14,15,17,18)$. These studies consistently found that by increasing depression, significant decrease occurs in the patients' QOL (Table 1). Demographic factors such as age, income, and occupational status are analyzed in most studies $(14,15,17,18)$ regarding their impacts on the QOL. For example, these studies indicated the existence of positive significant association between family income, educational status, and having an occupation with some aspects of QOL among patients with RA. No significant association was found between gender and QOL. Other Studies indicated that health status and enabling factors had a direct effect on QOL $(8,16)$. Self-care behaviors, predisposing, reinforcing and enabling factors had an indirect effect on QOL through health status. Health status, self-care behaviors, and enabling factors are more powerful predictors of QOL in patients with RA, respectively. In the current study, negative significant associations were found among complications of RA including: co-morbidity, pain, disease severity, body limitation, symptom, VAS (visual analogue scale) measures for pain, joint stiffness, and fatigue with QOL $(\mathrm{P}>0.05)(9,11,12,14,15,18)$.

\section{Conclusions}

It is important to note that, RA has a negative impact on QOL (19). In the current review, QOL score was relatively low for the Iranian patients. In the studies by Birtane et al. (20), Ranzolin et al. (21), and Tander et al. (5) QOL scores were $55.5,54.4$, and 55.5 respectively, which were compatible with that of the current study. Whereas, Lapsley et al. (22) in Brazil reported QOL score as 75.4; it seems that QOL had a little better situation in Brazil comparing the results of the other similar studies. QOL is a multidimensional concept which encompasses physical health, psychological status, level of independence, social relationships, and people's relationships with salient features of their environment (11). The study by Kalaly Jouneghani et al. in Iran showed that aerobic exercises can improve the QOL (13). The studies by Razavian et al. in Iran (17) and Lee in South Korea (3) found that preventing the aggravation of functional disability is a crucial component to improve the healthrelated quality of life (HRQOL) of patients with RA. According to another study, depression and fatigue should be properly investigated and managed to improve HRQL (23). 
Shokri A et al.

\begin{tabular}{|c|c|c|c|c|c|c|}
\hline Study & Year & Location & Sample Size & Demographics & QOL Assessment Tools & Correlation/Relationship \\
\hline Pakpour et al. (11) & 2013 & Qazvin & 197 & $\begin{array}{l}\text { Mean } \pm \text { SD of } \\
\text { age: } 23.25 \pm 4.98 \text { years, } \\
\text { Female: } 79 \%\end{array}$ & SF-36 Questionnaire & $\begin{array}{l}\text { Patients with at least one co-morbidity reported lower } \\
\text { HR-QOL compared with those without any co-morbid- } \\
\qquad \text { ity }(\mathrm{P}<0.001)\end{array}$ \\
\hline Kolahi et al. (9) & 2011 & Tabriz & 100 & $\begin{array}{c}\text { Mean } \pm \text { SD of age: } \\
45.6 \pm 7.1 \text { years, } \\
\text { Female: } 100 \%\end{array}$ & SF-36 Questionnaire & $\begin{array}{l}\text { Negative correlation between pain, mental, and physi- } \\
\text { cal health in subjects with } \mathrm{RA}(\mathrm{P}<0.001)\end{array}$ \\
\hline $\begin{array}{l}\text { Kalaly Jouneghani } \\
\text { et al.(13) }\end{array}$ & 2011 & Isfahan & 23 & $\begin{array}{l}\text { Mean } \pm \text { SD of age: } \\
47.09 \pm 6.1 \text { years, } \\
\text { Female: } 100 \%\end{array}$ & SF-36 Questionnaire & $\begin{array}{c}\text { The relationship between aerobic exercises and QOL } \\
\text { was significant }(\mathrm{P}<0.001) \text {. The relationship between } \\
\text { disease severity and QOL was insignificant }\end{array}$ \\
\hline Alishiri et al. (12) & 2011 & Tehran & 80 & $\begin{array}{l}\text { Mean } \pm \text { SD of age: } \\
43.20 \pm 11.8 \text { years, } \\
\text { Female: } 87.5 \%\end{array}$ & SF-36 Questionnaire & $\begin{array}{l}\text { Disease severity is associated with physical function- } \\
\text { ing scale, but not mental HR-QOL }\end{array}$ \\
\hline Nadrian et al. (8) & 2011 & Yazd & 181 & $\begin{array}{c}\text { Mean } \pm \text { SD of } \\
\text { age: } 45.54 \pm 13.61 \\
\text { years, Female: } 79 \%\end{array}$ & $\begin{array}{l}\text { MOS-SF-20 AIMS2-SF } \\
\text { Questionnaire }\end{array}$ & $\begin{array}{c}\text { There is a significant relationship between QOL, health } \\
\text { status and self-care behaviors in patients with RA }(\mathrm{P}< \\
0.01) \text {. Health status and self-care behaviors had } 75.8 \% \text { of } \\
\text { total QOL variance. Self-care behaviors had } 31.1 \% \text { of total } \\
\text { health status variance, as well }\end{array}$ \\
\hline Nadrian et al.(16) & 2009 & Yazd & 181 & $\begin{array}{l}\text { Mean } \pm \text { SD of age: } \\
45.54 \pm 13.61 \text { years, } \\
\text { Female }: 79 \%\end{array}$ & $\begin{array}{l}\text { MOS-SF-20 AIMS2-SF } \\
\text { Questionnaire }\end{array}$ & $\begin{array}{l}\text { There is a significant relationship between QOL and } \\
\text { health status factors, enabling factors, self-care be- } \\
\text { haviors factors, predisposing factors and reinforcing } \\
\text { factors }(\mathrm{P}<0.001) \text {. }\end{array}$ \\
\hline $\begin{array}{l}\text { Askary-Ashtiani et } \\
\text { al.(10) }\end{array}$ & 2009 & Tehran & 380 & $\begin{array}{c}\text { Mean } \pm \text { SD of age: } 57.8 \\
\pm 11.5 \text { years, Female } \\
: 54.7 \%\end{array}$ & $\begin{array}{l}\text { SF-36 AIMS2-SF Ques- } \\
\text { tionnaire }\end{array}$ & $\begin{array}{l}\text { Moderate to high relationship was found among body } \\
\text { limitation, symptom, and VAS measures for pain, joint } \\
\text { stiffness, and physician's global assessment }(\mathrm{P}<0.01)\end{array}$ \\
\hline $\begin{array}{l}\text { Monjamed and } \\
\text { Razavian (14) }\end{array}$ & 2008 & Tehran & 190 & $\begin{array}{l}\text { Range of age: } 18< \\
\text { years, Female: } 67.4 \%\end{array}$ & QOL Questionnaire & $\begin{array}{l}\text { Negative relationship was found between signs and } \\
\text { symptoms such as pain severity, fatigue severity, anxi- } \\
\text { ety, disability, depression severity and QoL. Age, mar- } \\
\text { riage status, occupational status, number of children, } \\
\text { family income, duration of disease, and physiotherapy } \\
\text { are significantly associated with QOL }(\mathrm{P}<0.001) \text {. No } \\
\text { significant relationship was observed between gender, } \\
\text { and physiotherapy and QOL }(\mathrm{P}>0.05)\end{array}$ \\
\hline Razavian et al. (17) & 2009 & Tehran & 190 & $\begin{array}{c}\text { Range of age: } 18< \\
\text { years, Female: } 67.4 \%\end{array}$ & QoL Questionnaire & $\begin{array}{l}\text { No significant relationship was observed between de- } \\
\text { pression and QOL }(\mathrm{P}<0.001) \text {. Significant relationship } \\
\text { was found between age, marriage status, occupational } \\
\text { status, number of children, family income, duration } \\
\text { of disease, physiotherapy, and QOL }(\mathrm{P}<0.001) \text {. Insig- } \\
\text { nificant relationship was observed between gender, } \\
\text { physical activity and QOL }(\mathrm{P}>0.05)\end{array}$ \\
\hline Atapoor et al. (15) & 2002 & Kerman & 100 & $\begin{array}{l}\text { Mean } \pm \text { SD of age: } \\
\text { 19-80 years, Female: } \\
80 \%\end{array}$ & HAQ questionnaire & $\begin{array}{l}\text { Insignificant relationship was found between depres- } \\
\text { sion, age and complication (number of involved } \\
\text { joints) of RA with disability }(\mathrm{P}<0.001) \text {. Family income, } \\
\text { educational status and occupation are associated } \\
\text { with improving QOL aspects }(\mathrm{P}<0.05) \text {. Insignificant } \\
\text { relationship was observed between gender, duration } \\
\text { of disease and residential status with disability }\end{array}$ \\
\hline
\end{tabular}

Prevalence of depression in patients with RA vary between $14 \%$ and $46 \%$, and even in some studies the prevalence of depression is reported up to $65 \%$ (24). Some studies reported that depression is associated with reduced health status, as well as higher pain, fatigue, and reduced QOL $(9,21,25)$. According to the present study, depression which appears to be a key factor affecting QOL should be prevented. Although controlling pain is an indication of successful treatment, despite the treatment, the majority of patients with RA have considerable amounts of pain
(9). Severe pain could impede the individual's work, daily activities and QOL (21). The studies by Ranzolin et al. (21), Kolahi et al. (9), and Monjamed et al. (18) indicated insignificant association between pain and QOL. The present study also confirms previous findings. Therefore, almost all of the drugs currently used to treat RA, such as antiinflammatory drugs, disease-modifying anti-rheumatic drugs (DMARDs), and biological drugs, all target pain relief to a greater or lesser extent (9). In the Iranian studies, the age had a major influence on QOL. As expected, 
Shokri A et al.

similar to the findings of other studies, older individuals had poorer health status than the younger ones (22, $26,27)$. In the evaluated studies, some items such as high education, higher income, marriage, and occupation were reported as factors improving the patients' QOL. The results of most studies in this field confirm these items (22). In the evaluated studies, there was insignificant association between gender and QOL among patients with RA. These findings were also supported by Bedi et al. (27) and Ranzolin et al. (21); whereas, the other studies (18, 22, 28) found the association between gender and QOL. It is important to note that, in all of these studies, female obtained lower scores than male in all domains of QOL (18). Many studies found fatigue as a major determinant for quality of life of patient with RA $(9,29)$. In the present study, fatigue, disease activity scores, and disease duration had negative significant association with QOL. Based on the other studies QOL among patients with RA is correlated with disease duration and disease activity scores $(2,18)$. Finally, the current study findings showed that health status and enabling factors had a direct effect on QOL. Self-care behaviors, predisposing, reinforcing and enabling factors had an indirect effect on QOL through health status. Health status, self-care behaviors, and enabling factors were more powerful predictors of QOL in patients with RA, respectively. Although self-care behaviors are weaker predictors of QOL than health status, but due to the strong association between self-care behaviors and health status it could be concluded that self-care behaviors indirectly and through health status affect QOL $(17,21,27)$. The present study attempted to systematically summarize the findings of conducted studies on QOL among the patients with RA. The most important limitation of this study was different data collection and reporting methods used in the evaluated studies. Also, the evaluated studies may not reflect the QOL of all patients with RA in Iran, and further studies are needed. Despite these limitations, all of the articles were found through accurate and complete research. To improve the QOL, all health professionals should consider all dimensions of QOL, comprehensively. On the other hand, due to the interactive nature of these aspects, improving one aspect can lead to improvement in other aspects. Due to the chronic nature of RA, promoting QOL and adherence to therapies could be achieved through convincing the patients. Therefore, identification of the weak points and planning for them at all levels, individual to the community level, is suggested. Finally, it is important to note that improving QOL could be achieved through empowering patients by their participation in the service delivery process and decision making, and for this purpose, healthcare professionals should focus on self-care abilities of the patients and reinforcing them by training.

\section{Funding/Support}

This study was funded by the Health Management and
Economic Research Centre of Isfahan University of Medical Sciences.

\section{References}

1. Khanna D, Arnold EL, Pencharz JN, Grossman JM, Traina SB, Lal A, et al., editors. Measuring process of arthritis care: the Arthritis Foundation's quality indicator set for rheumatoid arthritis.; Seminars in arthritis and rheumatism.; 2006; Elsevier; pp. 211-37.

2. Jacobi CE, Boshuizen HC, Rupp I, Dinant HJ, van den Bos GA. Quality of rheumatoid arthritis care: the patient's perspective. Int $J$ Qual Health Care. 2004;16(1):73-81.

3. Lee TJ, Park BH, Son HK, Song R, Shin KC, Lee EB, et al. Cost of illness and quality of life of patients with rheumatoid arthritis in South Korea. Value Health. 2012;15(1 Suppl):S43-9.

4. Salesi M, Farajzadegan Z, Karimifar M, Mottaghi P, Sayed Bonakdar Z, Karimzadeh H. Disease activity index and its association with serum concentration of anti-cyclic citrullinated peptide 1 (anti-CCP1) in patients with rheumatoid arthritis. Razi J Med Sci. 2010;17(74):15-21.

5. Tander B, Cengiz K, Alayli G, Ilhanli I, Canbaz S, Canturk F. A comparative evaluation of health related quality of life and depression in patients with fibromyalgia syndrome and rheumatoid arthritis. Rheumatol Int. 2008;28(9):859-65.

6. Mottaghi P, Karimzade H. Does chloroquine decrease liver enzyme abnormalities induced by methoterexate in patients with rheumatoid arthritis? J Res Med Sci. 2005;10(3):135-8.

7. Moher D, Liberati A, Tetzlaff J, Altman DG, Prisma Group . Preferred reporting items for systematic reviews and meta-analyses: the PRISMA statement. Ann Intern Med. 2009;151(4):264-9.

8. Nadrian H, Morovati Sharifabad M, Mirzaei A, Bahmanpur K, Moradzadeh R, Shariati A. Relationship Between Quality of Life, Health Status and Self-care Behaviors in patients With Rheumatoid Arthritisi in Yazd (central Iran). Ilam Uni Med Sci. 2011;19(2):15-25.

9. Kolahi S, Khbazi A, Hajaliloo M, Namvar L, Farzin H. The evaluation of quality of life in women with rheumatoid arthritis, osteoarthritis and fibromyalgia as compared with quality of life in normal women. Internet J Rheumatol. 2011;7(1):399-407.

10. Askary-Ashtiani AR, Mousavi SJ, Parnianpour M, Montazeri A. Translation and validation of the Persian version of the Arthritis Impact Measurement Scales 2-Short Form (AIMS2-SF) in patients with rheumatoid arthritis. Clin Rheumatol. 2009;28(5):521-7.

11. Pakpour AH, Zeidi IM, Hashemi F, Saffari M, Burri A. Healthrelated quality of life in young adult patients with rheumatoid arthritis in Iran: reliability and validity of the Persian translation of the PedsQL 4.0 Generic Core Scales Young Adult Version. Clin Rheumatol. 2013;32(1):15-22.

12. Alishiri GH, Bayat N, Salimzadeh A, Salari A, Hosseini SM, Rahimzadeh S, et al. Health-related quality of life and disease activity in rheumatoid arthritis. J Res med Sci Official J Isfahan Univ Med Sci. 2011;16(7):897.

13. Kalaly Jouneghani N, Rahnama N, Bambaeichi E, Jafari Y, Riahi Z. The Effect of eight weeks of aerobic exercise on quality of life and pain in patients with rheumatoid arthritis. J Res Rehabil Sci. 2011;7(3).

14. Monjamed Z, Razavian F. The effects of disease signs and symptoms on quality of life in patients with rheumatoid arthritis Referred to hospitals of Tehran University of Medical Sciences. $J$ Qom Univ Med Sci. 2008;1(1):27-35.

15. Atapoor J, Shakibi MR, Rajabizadeh G, Sarotehrigi M. The relationship between depression and disability in patients with Rheumatoid arthritis in Kerman. J Kerman Univ Med Sci. 2002;9(2):79-85.

16. Nadrian H, Sharifabad MAM, Salehabadi HS. Paradims of rheumatoid arthritis patien ts quality of life predictors based on path analysis of the Precede model. Hormozgan Med J. 2009;14(1):32-44.

17. Razavian F, Monjamed Z, Abbasi M, Kazemnejad A. Investigate the relationship between depression and quality of life in patients with rheumatoid arthritis. Daneshvar Shahed Univ. 2009;16(80): 27-34.

18. Monjamed Z, Varaee S, Kazemnejad A, Razavian F. Quality of life in patients with rheumatoid arthritis. J Nurs MidwiferyTehran Univ Med Sci Health Serv . 2008;13(3):57-66. 
19. Lima MG, Barros MB, Cesar CL, Goldbaum M, Carandina L, Ciconelli RM. Health related quality of life among the elderly: a population-based study using SF-36 survey. Cad Saude Publica. 2009;25(10):2159-67.

20. Birtane M, Uzunca K, Tastekin N, Tuna H. The evaluation of quality of life in fibromyalgia syndrome: a comparison with rheumatoid arthritis by using SF-36 Health Survey. Clin Rheumatol. 2007;26(5):679-84.

21. Ranzolin A, Brenol JC, Bredemeier M, Guarienti J, Rizzatti M Feldman D, et al. Association of concomitant fibromyalgia with worse disease activity score in 28 joints, health assessment questionnaire, and short form 36 scores in patients with rheumatoid arthritis. Arthritis Rheum. 2009;61(6):794-800.

22. Lapsley HM, March LM, Tribe KL, Cross MJ, Courtenay BG, Brooks PM, et al. Living with rheumatoid arthritis: expenditures, health status, and social impact on patients. Ann Rheum Dis. 2002;61(9):818-21.

23. Fabregas BC, de Avila RE, Faria MN, Moura AS, Carmo RA, Teixeira AL. Health related quality of life among patients with chronic hepatitis C: a cross-sectional study of sociodemographic, psy- chopathological and psychiatric determinants. Braz J Infect Dis. 2013;17(6):633-9.

24. Perkins AJ, Stump TE, Monahan PO, McHorney CA. Assessment of differential item functioning for demographic comparisons in the MOS SF-36 health survey. Qual Life Res. 2006;15(3):331-48.

25. Zyrianova Y, Kelly BD, Gallagher C, McCarthy C, Molloy MG, Sheehan J, et al. Depression and anxiety in rheumatoid arthritis: the role of perceived social support. Ir J Med Sci. 2006;175(2):32-6.

26. Li L, Wang HM, Shen Y. Chinese SF-36 Health Survey: translation, cultural adaptation, validation, and normalisation. J Epidemiol Community Health. 2003;57(4):259-63.

27. Bedi GS, Gupta N, Handa R, Pal H, Pandey RM. Quality of life in Indian patients with rheumatoid arthritis. Qual Life Res. 2005;14(8):1953-8.

28. Dachs JNW, Santos APR, Rocha AP. Self-assessment of health status in Brazil: analysis of PNAD / 2003 data. Ciênc public health 2006;11(4):887-94.

29. Rupp I, Boshuizen HC, Jacobi CE, Dinant HJ, van den Bos GA. Impact of fatigue on health-related quality of life in rheumatoid arthritis. Arthritis Rheum. 2004;51(4):578-85. 